\title{
EXPLORING GENDER ROLES IN THE STORY OF I LA GALIGO
}

\author{
Murni Mahmud \\ Fakultas Bahasa dan Sastra Universitas Negeri Makassar \\ E-maildwimurnye@yahoo.com
}

\begin{abstract}
This paper aims at exploring the gender roles in the story of I La Galigo. This story is an epic of the Bugis society featuring the adventure and the lives of the first humans occupying and living in the Earth. Based on the analysis, gender roles can be seen in the story, such as the roles of Datu Palinge' as the wife who can influence the decision making of the King, Sang Patoto'e. The reflection of gender can also be seen in the expected behaviors of Bugis men and women for masculinity and femininity. Men are expected to be warani (brave) and women are expected to be malebbi' (modest). These expected behaviors can be seen from women characters, We Nyili' Timo and We Datu Sengngeng, and from men characters, Batara Lattu' and Sawerigading. Another gender issue can also be seen in the pattern of patrilineal society and the tendency to marginalize women's position.
\end{abstract}

Key words: Bugis society, I La Galigo, Gender roles.

\section{MENGUPAS PERAN JENDER DALAM CERITA I LA GALIGO}

Abstrak Makalah ini mengupas peran jender dalam cerita I La Galigo. Cerita ini adalah kisah sejarah masyarakat Bugis tentang petualangan manusia pertama yang tinggal dan hidup di bumi. Hasil analisis menunjukkan adanya peran jender dalam cerita ini, seperti peran Datu Palinge', istri dari Sang Patoto'e yang dapat mempengaruhi pengambilan keputusan. Reflekesi jender juga terlihat pada sikap panutan yang diharapkan oleh masyarakat Bugis terkait maskulin dan feminim. Laki-laki Bugis diharapkan menjadi seorang pemberani (warani) sedangkan perempuan Bugis hendaknya menjadi perempuan yang angun atau dalam istilah Bugis malebbi'. Sikap ini dapat dilihat pada tokoh perempuan We Nyili' Timo dan We Datu Sengngeng, dan juga dari tokoh laki-laki, Batara Lattu' and Sawerigading. Isu lain seputar jender dapat juga terlihat seperti pola patrilineal yang mengutamakan peran laki-laki dan juga kecenderungan untuk memarginalkan posisi perempuan.

Kata-kata kunci: Masyarakat Bugis, La Galigi, Peran jender

\section{INTRODUCTION}

Indonesia is a country which is rich with language and culture. Bugis society is one of them, located mainly in South Sulawesi. As the main ethnic group in South Sulawesi, Bugis society is known to maintain their own culture and tradition, although they adjust to the increasing needs on modern Indonesian society nowadays.

A crucial point regarding Bugis society is their cultural concept of siri' (shame). Matthes stated that, siri' is the feeling of being 'ashamed, diffident, shy, shame, sense of honour, and disgrace' (cited in Graham, 2001:2). Idrus (2003), for example, did research on Bugis women integrating the roles of gender, siri', and sexuality. Another study (2008) is by Mahmud, by looking at politeness concept of Bugis people which is embodied by the concept of siri' na pesse (shame and compassion).

Other studies by Millar (1983, 1989), Acciaoli (1989), Brawn (1993), Pelras (1996), Robinson and Paeni (1998), and Alimi (2012) bring the ideas that Bugis society has plenty of socially and culturally distinct and unique facts that are worthy of discussion. Several of these studies explored other important facts in Bugis society such as social status and religion. Bugis people are also rich in historical texts, usually written in the font of lontara'. Studies on Bugis texts had also been conducted by plenty of scholars

\footnotetext{
Murni Mahmud, graduated from IKIP Ujung Pandang in 1991, finished her Master Degree at American Studies Graduate Program, Gadjah Mada University 1999, and did her Ph.D at Anthropology Department, the Australian National University 2008. She is a lecturer at English Department of UNM, majoring in Anthropolinguistics, Sociolinguistics, and Discourse Analysis.
}

(Abidin \& Macknight, 1974; Sirk, 1983; Tol, 1996; Koolhorf, 1999; and Macknight, 2006).

One of these important historical texts is the story of I La Galigo whose original manuscripts were kept in Netherland. The manuscripts were first collected by Colliq Pujie Arung Pancana in the $19^{\text {th }}$ century. This story had been brought into the stages in other countries in the world such as in Europe, America, and Australia. Proving to be one of the important masterpieces of the world, Memory of the World (MOW) had been awarded by UNESCO in 2011 (Rahman 2012).

There have been a lot of books about the story of I La Galigo. Rahman (2012), for example, wrote the story from the beginning until the birth of I La Galigo. The story started when Sang Patoto'e sent his oldest son, Batara Guru, to start occupying and managing the lives in the Earth. The story then continued until the birth of I La Galigo, who was the great grandson of Batara Guru. Another book still continues to depict the adventure story after I La Galigo birth.

This paper focuses to explore this Bugis historical text from gender perspectives. The analysis is based on the novel story written by Rahman (2012). Several important women characters such as Datu Palinge', We Nyili' Timo, We Datu Sengngeng, and We Cuda'i become the central of this discussion. I examine their characters as women in Bugis society which brings the ideas of gender roles. I employed the concept of Bugis behaviour for men and women that have been discussed in the literature of Bugis society, especially the concept of siri'(shame) In addition, I observed 
gender roles in the story based on the concept of patrilineal society and other gender issues such as marginalisation or discrimination that have been encountered by women.

\section{Gender in Bugis Society}

In early time of the Bugis history, women are said to possess high social status. Baso and Idrus (2002:199) had noted that 'some of the first rulers, who descended to earth and whose superior status was acknowledged, were women'. Rottger-Rossler also emphasized that the first divine ruler of Bontoloe was a woman, BombongKoasa. This woman came out from a bamboo trunk and then become the king of Makassar in Gowa (cited in Baso and Idrus, 2002:199).

According to Pelras (1996:160), Bugis women enjoy their 'distinct but complementary roles'. Therefore, women's participation in public space can be seen in Bugis society, as noted by Brooke:

All the offices of state, including even that of arumatoa, are open to women; and they actually fill the important posts of government; four out of the six great chiefs of Wajo being at present females. These ladies appear in public like the men; ride, rule, and visit even foreigners, without the knowledge or consent of their husbands (Cited in Pelras 1996:164).

However, Bugis people have different expectations for Bugis men and women. Pelras (1996:163) states that, for Bugis, 'whoever, although a man, has female qualities, is a woman; and although a woman, has male qualities, is a man'. This shows that Bugis men and women have already got different qualities as either a man or a woman.

Due to the above qualities as men and women, Bugis people have already acquired specific roles for each of them, based on their existence as men and women. Specific tasks are given to women and some others are specific for men. This is in reference to the Bugis saying noted by Millar (1983:163) that 'the woman's domain is around the house while the man's domain reaches 'the borders of the sky'. Therefore, women's roles are around the house, whereas for men, their roles may spread outside of the house.

Jayadi (2002:1-2) notes that Bugis women are expected to be (1) mancaji makkunrai 'to be a woman', (2)mancaji missing dapureng 'to know the area of the kitchen', (3) mancajii mattaro'to be a money keeper', (4) mancaji baliperi' 'to accompany in all conditions', and (5) makkunrai sirupa'to be only as a woman' (Cited in Mahmud, 2008). This shows that the main area for Bugis women are mostly in domestic roles such as cooking and arranging money spent for the household.

Mattulada also discusses Bugis women's roles based on pangngaderreng 'a customary law' from Latoa, another kind of Bugis text. It was stated that men and women may both be involved in deliberations, but women's opinions can only be used as a complement and not to make a final decision because women are considered to have 'physical' as well as 'psychological' weaknesses (1995:440). This means that women's opinion is just secondary and just be taken as suggestion only to the main decision.

Different expectations for Bugis men and women are also in terms of behaviour. The concept of being malebbi' 'modesty' is encapsulated in Bugis men and women's behaviour. Idrus (2003:58) notes that being modest for women can be from their 'non-aggressive behaviour' or 'female-hiddenness', whereas for men, being malebbi' can be by being warani 'brave' or by showing 'male openness'. Men should be warani 'brave', maringngerang 'conscientious or alert', and marisaliweng 'visible' indicating a 'male-openness' which is the opposite of 'female hiddenness' (Idrus, 2003:58).

Idrus (2003:55) further mentions that there are some notions underlying the modesty of Bugis women. Bugis women are like a kaca 'mirror', pennépinceng 'porcelain plate', or tello' 'egg'. These notions indicate that women need to be carefully protected since mirrors, porcelain, and eggs are easily broken and once broken, they become worthless and useless.

Furthermore, female Bugis are often considered to be maperreng 'hidden', indicating that they should be able to control themselves. This means that Bugis women should not show aggressiveness. Idrus (2005:45) states that "women have to restrain themselves from expressing desire, while men's desire should be demonstrated'.

Millar also notes that Bugis men need to behave 'aggressively and formally'. On the other hand, Bugis women are required to act 'cautiously and informally' (1983:489). This means that aggressiveness and formality are men's characteristics whereas women are identical with cautiousness and informality. Idrus (2005:46) further confirmed that

The aggressiveness and the formality of a man's behavior are associated with his performance and social location. By contrast, a woman's passive behavior is associated with her honor. To complement the behavior expected of men, women are supposed to be obedient and timid, not only to show her honor (alebbireng), but also to prevent transgression of siri'.

Therefore, it can be seen that the Bugis norm siri' 'shame' is one aspect concerning the gender roles in Bugis society. In order to be malebbi', women should be masiri' and try not to be masiri', not only for the women themselves but also for other people.

Because of siri', women are expected to have good attitude. Women should be malebbi', not aggressive, as they are the honour for their family. 'A Bugis woman is placed in a 'position of honour,' as a jewel (intang paramata) of the family' (Idrus, 2005). Mahmud (2008) also confirms that the person who possesses siri' will follow the principal taro ada, taro gau' 'similar words and similar actions'. This principle means what is said should be suitable to what is done. It is not laing ada, laing gau' 'different words, different actions'. 


\section{Exploring gender roles in the story of I La Galigo}

This section is deeply examining the roles of gender in the story of I La Galigo. The main focus is on several women characters. Throughout the story, women are put in different positions which may reveal their gender roles.

\section{Gender Roles in Decision Making}

I start with Datu Palinge', who was the wife of Sang Patoto'e. It is explained in the story that Datu Palinge'and Sang Patoto'eare the First Rulers who lived in the Kingdom located in the sky known as Istana Boting Langi'. They were the rulers of the life in the sky, together with another Kingdom known as Istana Peretiwi, located in the sea. Sang Patoto'e always asked his wife's opinion when he wanted to take decision. In fact, he sometimes followed his wife's suggestion.

It is explained in the story that there was the Earth which was still empty with no people in it. Sang Patoto'e then initiated to send one of his sons to occupy the Earth. Sang Patoto'e then discussed with all of the followers in the Kingdom. Then he came to his decision to choose his older son to become the ruler of the first Kingdom in the earth, known as Istana Ale Luwu', which was then known as Batara Guru. However, he waited for his wife's suggestion about that.

Sang Patoto'e hidup tenteram dan bahagia.Dia bertindak sebagai penguasa tunggal.Tetapi, bila ingin memutuskan sesuatu, dia selalu berdiskusidengan sang istri. Dalam ha ltertentu, Sang Patoto'e sering mengikuti saran istrinya (Rahman, 2012:13).

(Sang Patoto'e lived prosperously and happily. He became the single ruler. However, when he wanted to make a decision, he always discussed with his wife. In a certain matter, Sang Patoto'e sometimes agreed with her wife's suggestion).

The same case happened when he wanted to take a decision to set other two kingdoms in the earth beside the Kingdom of Ale' Luwu as the oldest Kingdom. In order to maintain the strength of humans in the Earth, he needed to set other kingdoms in other parts in the Earth, namely, Kingdom of Toppo Tikka' and Wewang Riu':

Sang Patoto'e duduk merenung di kursi kebesarannya di Istana Sao Kutta Parappa'e sembari menunggu kedatangan permaisuri. Ia ingin meminta pendapat permaisuri tentang rencananya menurunkan istana ke Bumi (Rahman, 2012:111).

(Sang Patoto'e was sitting in his chair at Sao Kutta Parappa'e while he was waiting for his Queen. He wanted to ask the Queen's opinion about his plan to set other kingdoms in the Earth)

This shows that the wife in Bugis history had acquired good roles in determining the decisions. Throughout the story, Datu Palinge' always was given a chance to show her opinion in every matters occurred. Sang Patoto'e always discussed with her wife and waited for his wife to ask for her opinion. This shows that in early time in Bugis history, women had been given good chance to have their opinions.

\section{Gender Roles in Expected Behaviors}

Another reflection of gender roles in the story of I La Galigo is the expected behavior of women. This can be seen in the two women characters, namely We Nyili' Timo and We Datu Sengngeng.These two women represented the expected behavior of women in Bugis society that is by being malebbi' (modest), by acting firmly and not aggressively.

We Nyili' Timo, the wife of Batara Guru, the first King in the Earth, sent by Datu Patoto'e, resembles the expectation of Bugis women in society. In the first time, Batara Guru and We Nyili' Timo met each other, We Nyili' Timo did not show her love, although Batara Guru had tried to attract her attention:

Batara Guru sangat terpukau melihat WeNyili' Timo yang sangat cantik jelita. Ia menyapanya, tetapi We Nyili' Timo hanya menunduk dalam diam... Batara Guru lalu mengajak We Nyili' Timo menuju Istana Ale Luwu'. Tetapi, We Nyili’ Timo hanya diam membisu... We Nyili' Timo tetap menunduk di atas usungannya di bibir pantai. Ia tak mau menentang mata Batara Guru (Rahman, 2012:82)

Batara Guru was very impressed with We Nyili' Timo who was very beautiful. He tried to talk, but she did not raise her head, just look up down and kept silent. Batara Guru then asked her to go to the palace, but We Nyili' Timo just kept silent. She just looked up down and never wanted to have eye contact with Batara Guru.

This shows that We Nyili' Timo had tried to maintain her feeling and love showing that she was malebbi' (modest). As expected by Bugis society, women should be malebbi' by not showing her aggressiveness. By looking up down and not keeping eye contact, women in Bugis had shown her modesty or her being malebbi', not aggressive, although deep in their hearth, they feel the love.

We Datu Sengngeng, another character in the story also reflected the women roles in Bugis society. We Datu Sengngeng, in the story was the princess in another Kingdom known as Toppo' Tikka. As stated in the story, after Batara Guru, the older son of Sang Patoto'e settled the life in the Kingdom of Ale Luwu', Sang Patoto'e then decided to send two other Kingdoms to the Earth to accompany the old Kingdom, Ale Luwu'. These two manurung'sent from the sky' Kingdom were Toppo'Tikka and Wewang Riu'. Each of them had the King. Toppo' Tikka had two beautiful daughters, in which one of them would become the wife of Batara Lattu', who was the son of Batara Guru and We Nyili' Timo.

In the story, it was explained how was the meeting of Batara Lattu' and We Datu Sengngeng. Both of them had fallen in love each other. Batara Lattu' could not wait to meet We Datu Sengngeng, who was very beautiful with her very long hair, twice of her height. We Datu Sengngeng had also felt the love since Batara Lattu' had come to her dream. Despite her love to Batara Lattu', We Datu Sengngeng chose not to show his love in front of Batara Guru. She 
always tried not to express her feeling to Batara Lattu'.

Batara Lattu' menyerahkan daun sirih khusus kepada We Datu Sengngeng. Dengan malumalu, We Datu Sengngeng mengambil daun sirih tersebut.Tetapi daun sirih hanya diremasnya tanpa dimasukkan kemulut. Ia tampak malu-malu dan canggung (Rahman, 2012:192).

Batara Lattu'offered betel leaves to We Datu Sengngeng. Looking ashamed, We Datu Sengngeng took those leaves. But, she didn't eat. She was still ashamed and reluctant.

When Batara Lattu' gave daun sirih (betel leaves) which was the symbol of love, to We Datu Sengngeng, We Datu Sengngeng just took and kept in her hand while looking up down and never trying to look at Batara Lattu'. Deep in her hearth, she also liked Batara Lattu' since Batara Lattu' came in her dream. This is because as a woman, it is not acceptable for her to expose her love.

When they already got married to each other, BataraLattu' as the man had to persuade or flitter his wife in order that We DatuSengngeng was sure of his love.

Di atas ranjang, We Datu Sengngeng masih terdiam dan membelakangi suaminya... BataraLattu' terus membujuk dan merayu istrinya dengan katakata sayang, lembut, dan romantis. Setelah tujuh kali terus merayu dan membujuk istrinya, We Datu Sengngeng pun berbalik kearah suaminya sambil meneteskan air mata...(Rahman, 2012:206)

In the bed, We Datu Sengngeng was still quiet and sat back from her husband. Batara Lattu' continued to persuade his wife with romantic words. After seven times, We Datu Sengngeng faced him with her tears.

This shows that women in Bugis society need to be modest or malebbi', by not showing her aggressiveness. We Datu Sengngeng represented that expected attitudes. This can be seen in We Datu Sengngeng, in which she just tried to look on the floor whenever Batara Lattu' was talking to her in their early marriage. Women should not be aggressive. Women should be modest. Although We Datu Sengngeng had fallen in love, she would rather not show to her husband directly. Her silence and tears became the symbol of her love. She demonstrated the expected behavior of Bugis women to be 'hidden' or maperreng, instead of being 'open' or marisaliwing.

When We Datu Sengngeng had to separate with her sister, when Batara Lattu was going back to Ale Luwu' with her wife, We Datu Sengngeng, We Adiluwu', her twin sister, gave advice to her sister:

Sebagai seorang istri, engkau harus patuh dan taat pada suamimu selama itu tidak melanggar perintah Sang Patoto'e...Engkau harus menjad ipermata yang indah buat kesenangan suamimu. Jangan pernah bersikap sesuatu yang bias membua jengkel atau marah suamimu.Jagalah siri' sebagai perempuan...(Rahman 2012:209)
As a wife, you must obey your husband as long as it does not obey the rules from Sang Patoto'e. You must become a beautiful jewelry for your husband. Never do something than can make your husband angry or annoyed. Keep your siri' as a woman.

This shows the symbol of women in Bugis society as a diamond or jewel. In Bugis, a good woman is symbolized as paramata mattappa' 'sparkling jewels' (Mahmud, 2008).Therefore, a woman should behave that can preserve their honor. As Idrus (2005) states that a woman is like a jewel 'intang paramata', which is the symbol of siri' of the family. We Datu Sengngeng in the above story, was expected to have good attitudes as a woman and as a wife in order to preserve her siri' 'shame or honor' in the family.

Another case can be seen in another woman character, I We Cudai'. This woman was the wife of Sawerigading, the son of Batara Lattu' and WeDatuSengngeng. I We Cudai' was the princess in China and chosen to be the wife of Sawerigading after Sawerigading, could not marry his twin sister, We Tenriabeng. After encountering many challenges through the sea voyages and battles, Sawerigading could marry I We Cudai'.

In the first time, I We Cudai' was not accepting the marriage proposal of Sawerigading because she was told that Sawerigading was very ugly man and she felt that she did not deserve it. Because of her refusal to her husband, Sawerigading then married to I We Cimpau', but then he left again because $I$ We Cimpau' was just a non-noble woman. Although later Sawerigading and I We Cudai' loved each other and had a son, I We Cudai' still did not want to admit Sawerigading as her husband because she was ashamed of her expression that she did not like Sawerigading. As a woman, she did not want to reject her words. If she then said that she loved Sawerigading, I We Cudai' said, "seluruh rakyat Ale Cina akan menertawakan. Aku benar-benarmalu.' (All people in China will laugh at me. I will be very ashamed.'

I We Cudai' had shown her feeling of being consistent with what she said. According to Bugis culture, one should be consistent with the possession of siri' (self-esteem). One who has siri' will follow the principal taro ada, taro gau' 'similar words and similar actions' (Mahmud 2008). This principle means that the ways of talking should correspond to the ways of behaving. It is not laing ada, laing gau' 'different words, different actions (Ibid). Even when she was given a birth to a baby boy, who was named $I$ La Galigo, she did not want to accept it. This indicates that the Bugis should have the principle of siri' and has to maintain that siri' in their words and attitudes. The man in this case should show his brevity and gentility. As stated by Idrus (2003), a man in Bugis should be warani 'brave'. This character can be seen in several men characters in the story of I La Galigo. One of the examples is Batara Lattu'. In his journey to find his predestined marriage, We Datu Sengngeng, he had to do the sea voyages for months by using the 
ship known as Tanete Manurung. In his adventure to win the love of We Datu Sengngeng, he had to try many ways and never gave up.Sawerigading, in his adventure to meet I We Cudai', who rejected the proposal marriage of Sawerigading, indeed faced many challenges. Sawerigading did not give up and managed to marry I We Cudai. Sawerigading had promised that he would never went back to Ale Luwu' Kingdom, if he failed in his journey.

Both of them, Batara Lattu' and Sawerigading had demonstrated the brave and gentle role of Bugis men to be maperreng, brave, and visible showing the male openness (Idrus, 2008), the expected character for Bugis men. In terms of being masculine, both of them demonstrated that they were brave in showing their love and desire. Batara Lattu'won the love of We Datu Sengngeng and showed that it was the man that should be aggressive, firmly, and gentle. Sawerigading won the love of I We Cudai', together with the somany refusals and requirements. Sawerigading had been brave and gentle and therefore, he resembles the man expectation for Bugis by being brave, gentle, and therefore, masculine.

\section{Gender Roles, Social Status, and Patrilineal Culture}

Another reflection of gender roles in this story is the patrilineal culture, emphasizing the roles of the men. We Nyili' Timo was the wife of Batara Guru, soon Batara Guru settled in the Kingdom of Ale Luwu'. She was also being sent from Sang Patoto'e and chosen as the Queen. Batara Guru as the King had already got five wife known as selir (other wives). However, it was not complete for Batara Guru if there were no queen, then We Nyili' Timo was then sent to be the Queen by Sang Patoto'e and Datu Palinge'. Batara Guru was in love with We Nyili'Timo and decided not to have selir. However, We Nyili' Timo said that there was no Queen if no selir. The five wives of the King actually function to serve all of the need of the King and the Queen. In practice, selir (other wives) not only served the King as wives but also served the Queen (permaisuri).

Therefore, it can be seen that early time in Bugis history, the man had been allowed to have more than one wife. That is the man who possesses the main roles. The acceptable genealogies are from the line of the King.

In the story, We Datu Sengngeng was given a birth to twins (men and woman) named Sawerigading and WeTenriAbeng. However, they should be separated as they might have been fallen in love together. In the decision to separate them, Sawerigading was decided to stay in the Kingdom because he was the man who then would become the next King in the Kingdom. It was We Tenriabeng, the daughter, that was sent to another place. Sawerigading in fact was going to marry We Tenriabeng after they met each other.

This shows that women have lower bargaining power than women. Because that is the man, according to patrilineal society, who will become the leader, women may be marginalized because of her inferior position. The man that was Sawerigading, who was chosen to stay in the Kingdom, because that was the man who became the leader. The woman, his sister, We Tenriabeng was chosen to be expelled from the Kingdom as she was not expected to be the King. Another thing that can be examined from this case is about the roles of social status in relation gender roles. In the story of Batara Guru and We Nyili' Timo, it can be seen that the Queen should be from the same level as the King. Other wives known as selir functioned to serve the King and the Queen. Throughout the story, Batara Guru was illustrated to be worried of not having a son born from the Queen, as that would become the next King in the Kingdom of Ale Luwu'. Other sons from other wives were not expected to become the King.

This shows that women and their position or social status will influence the treatment in the family and household. The Queen will be given high priority due to her status. The Queen should also be the same level as the King. Other wives or selir are then becoming the second priority.

The same case can also be seen in the adventure of Sawerigading and I We Cudai'. Because of her refusal to her husband, Sawerigading then married to I We Cimpau', but then he left again because I We Cimpau' was just a non-noble woman. The noble wife will be the primary option in the marriage.

This shows that besides the aspect of gender, status attained by the women themselves will also influential in Bugis society. The high treatments for women are also influenced by the status they have. This is in relation to Moreau's statement that 'each class speaks itself' (1984:59). This discussion also emphasized the important roles of social status in Bugis society that had also become the focus of discussion in the literature of Bugis society. Mahmud (2008:117) in the study of politeness in Bugis society, notes that 'the social status of a person requires a particular treatment in a particular situation'.

\section{CONCLUSION}

From the discussion above, it can be seen that gender roles are reflected in the story of I La Galigo. As a part of Bugis culture, especially Bugis history, the story of $I \mathrm{La}$ Galigo has served as the source of moral and attitudes for Bugis people.

Gender roles reflected in Bugis men and women characters are the symbol for Bugis history. This shows that in early time in Bugis history, Bugis men and women have embodied gender expectations. It is explained that the Bugis concept of siri' becomes the compass for Bugis men and women in behaving. Women in Bugis are required to be malebbi' and men are encouraged to be warani.

Other gender roles have been practiced by several women characters. In making decision, for example, women have been given a chance to participate. Although the roles are complementary, the chance given to women is the indicators that women are given high respect in Bugis society. 
Other gender issues are also experienced in the story such as the important roles of man in patrilineal society, which is also experienced by Bugis people. The man becomes the first important point in the family and household. In addition, women experienced marginalization due to her inferior position in the family and household.

Apart from the gender ideology, status for women is an important factor in acting the roles as women. High status women are given the first priority. This status may affect the notions on women's roles in Bugis society.

\section{REFERENCES}

Abidin, A.Z \& CC. Macknight.1974.The I La Galigo Epic Cycle of South Celebes and Its Diffusion. JSTOR.

Acciaioli, G. L. 1989. Searching for Good Fortune: The Making of a Bugis Shore Community at Lake Lindu, Central Sulawesi.Ph.D Thesis. Canberra: The Australian national University.

Alimi, M.Y. 2012. 'Head covering to live by: Cipo'cipo', Shari'ah, and women's experince of clothing in South Sulawesi'. Intersections: Gender and Sexuality in Asia and the Pacific, (30).

Baso, Z. A.\& Idrus, N.I. 2002. 'Women's Activism against Violence in South Sulawesi.' In K. Robinson and S. Bessel (eds.). Women in Indonesia: Gender, Equity, and Development. Singapore: Seng Lee Press Pte Ltd, pp 198208.

Brawn, D. M. 1993. Immanent Domains: Ways of Living in Bone, Indonesia. Ph.D Thesis. Anthropology Department, Michigan: the University of Michigan.

Graham, S. 2001. 'Negotiating Gender: Calalai' in Bugis Society.'Murdoch University.http:// wwwsshe.murdoch.edu.au/intersections/ issue6/graham.html, Accessed 11 March 2004.

Idrus, N. I. 2003. To Take Each Other: Bugis Practice of Gender, Sexuality, and Marriage. Ph.D Thesis. Canberra: Research School of Pacific and Asian Studies. Australian National University: 389.

Idrus, N. I. 2005. 'Siri', gender, and sexuality among the Bugis in South Sulawesi'.Antropologi Indonesia, 29(1).

Jayadi, A. 2002. 'Bias Jender pada KeluargaBugis Makassar'.http://situs.kesrepro.info/ gendervaw/jul/2002/gendervaw03.htm $>$ Accessed 11 March 2007
Koolhof, S. 1999. The 'La Galigo' A Bugis Encyclopedia and Its Growth.Bijdragen tot de taal-land-en Volkenkunde.

Macknight, CC. 2006. 'Review Article: I La Galigo, State Theater, Melbourne International Arts Festivals'. Review of Malaysia Indonesia Affairs, vol. 40, no 2, pp, 1431-8.

Mahmud, M. 2008. Politeness in Bugis.A Ph.D Thesis. Canberra, Australia: The Australian National University.

Mattulada.1995. Latoa: Satu Lukisan Analitis terhadap Antropologi Politik Orang Bugis. Ujung Pandang: Hasanuddin University.

Millar, S. B. 1983. 'On Interpreting Gender in Bugis Society', American Ethnologist,10(3): 477493.

Millar, S. B. 1989.Bugis Weddings: Rituals of Social Location in Modern Indonesia.Berkeley: Center for South and Southeast Asia Studies, University of California.

Moreau, N.B. 1984. 'Education, Ideology, and Class/ Sex Identity.' In C. Kramarae, M. Schulz and W. M. O'Barr (eds). Language and Power. USA: Sage Publications, Inc., pp43-61.

Pelras, C. 1996. The Bugis. Cambridge, Massachussets: Blackwell Publishers.

Rahman, D. R. 2011. La Galigo: Napak Tilas Manusia Pertama di Kerajaan Bumi. Yogyakarta: DIVA Press.

Robinson, K and Paeni, M. (eds.). 1998. Living Through Histories: Culture, History, and Social Life in South Sulawesi. Canberra: Research School of Pacific and Asian Studies, the Australian National University.

Sirk, U. 1983. The Buginese Language. Moscow: NAUKA Publishing House, Central Department of Oriental Literature.

Tol, R. 1996. 'A Separate Empire: Writings of South Sulawesi.' In Ann Kumar and John H. McGlynn (eds.). Illuminations: the Writing Traditions of Indonesia: Featuring Manuscripts from the National Library of Indonesia.Jakarta, New York and Tokyo: The LontarF 